\title{
POLA INTERAKSI ANAK DAN ORANGTUA SELAMA KEBIJAKAN PEMBELAJARAN DI RUMAH
}

\author{
Khamim Zarkasih Putro', Muhammad Adly Amri' ${ }^{2}$, Nuraisah Wulandari ${ }^{3}$, Dedek Kurniawan ${ }^{4}$ \\ ${ }^{1}$ Universitas Islam Negeri Sunan Kalijaga Yogyakarta, 2,3,4Universitas Islam Negeri Sumatera Utara Medan \\ E-mail: hamizarkasih@gmail.com, adlyamri32@gmail.com, wulandariuinsu@gmail.com, \\ dedek.kurniawan@uinsu.ac.id,
}

How to Cite:

Putro, K. Z., Amri, A. M., Wulandari, N., Kurniawan, D. (2020). Pola Interaksi Anak dan Orang tua Selama Kebijakan Pembelajaran di Rumah. Fitrah: Journal of Islamic Education, 1(1).124-140.

\begin{tabular}{lr}
\hline \multicolumn{2}{l}{ ARTICLE HISTORY } \\
Received & :18 July 2020 \\
Revised & :21 July 2020 \\
Accepted & $: 23$ July 2020 \\
Published & $: 25$ July 2020
\end{tabular}

\section{KEYWORDS:}

Interaction, Parents, Rules, Learning,

\begin{abstract}
This study aims to reveal the effectiveness of the implementation of learning from home, and patterns of interaction between parents and children during learning from home. Set the pattern of interaction between parents and children during the learning policy from home is very important to do, so that children can voluntarily learn, and parents can easily control and improve children's learning activities and outcomes at home. The method used in this research is a qualitative study based on descriptive studies, meaning that research methods require results in the form of descriptions, or a complete and complex depiction of research data and facts. In this case the depiction in question is the pattern of interaction between parents and children during distance learning or at home during the Covid-19 pandemic. The results showed that the position of parents in managing interactions with their children is very important for the continuity of learning. Interaction patterns of interaction between parents and children as the findings of this study show two patterns, direct interaction; in this case parents and children together follow the learning provided by the teacher. Indirect interaction in this case parents only as a facilitator, for the implementation of learning.
\end{abstract}

\section{RIWAYAT ARTIKEL}

Diterima :18 Juli 2020

Direvisi :21 Juli 2020

Disetujui :23 Juli 2020

Diterbitkan :25 Juli 2020

\section{KATA KUNCI:}

Interaksi, Orangtua, Kebijakan, Belajar

\begin{abstract}
ABSTRAK
Penelitian ini bertujuan untuk mengungkap efektivitas implementasi pembelajaran dari rumah, dan pola interaksi orang tua dan anak selama pembelajaran dari rumah. Mengatur Pola interaksi antara orang tua dan anak selama kebijakan pembelajaran dari rumah sangat penting untuk dilakukan, agar anak dapat dengan sukarela untuk belajar, dan orag tua dapat dengan mudah untuk mengontrol dan meningkatkan kegiatan dan hasil belajar anak di rumah. Metode yang digunakan dalam penelitian ini ialah penelitian kualitatif berbasis studi deskriptif, maksudnya metode penelitian yang menghendaki hasil dalam bentuk deskripsi, ataupun penggambaran secara utuh dan kompleks tentang data dan fakta penelitian. Dalam hal ini penggambaran yang dimaksud ialah pola interaksi antara orang tua dan anak selama melakukan pembelajaran jarak jauh atau di rumah selama pandemic Covid-19. Hasil penelitian menunjukkan bahwa posisi orang tua dalam mengatur interaksi dengan anak-anak mereka sangatlah penting demi keberlangsungan pembelajaran. Pola interaksi interaksi antara orang tua dan anak sebagai temuan dari penelitian ini menunjukkan dua pola, interaksi langsung, dalam hal ini orang tua dan anak bersama-sama mengikuti pembelajaran yang diberikan oleh guru. Interaksi tidak langsung dalam hal ini orang tua hanya sebagai fasilitator saja, bagi terlaksananya pembelajaran.
\end{abstract}




\section{PENDAHULUAN}

Dalam Undang-Undang Republik Indonesia Nomor 20 tahun 2003 mengenai Sistem Pendidikan Nasional, pasal 1 ayat 1 menyatakan bahwa: Pendidikan adalah bisnis sadar \& bersiklus buat mewujudkan suasana belajar dan proses pembelajaran agar anak didik secara aktif menyebarkan potensi dirinya buat memiliki kekuatan spiritual keagamaan, pengendalian diri, kepribadian, kecerdasan, akhlak mulia, dan keterampilan yang diperlukan dirinya, masyarakat, bangsa \& negara. (Kemendiknas, 2003).

Pendidikan tidak akan terlaksana tanpa adanya proses belajar yang berkesinambungan, dengan proses belajar seseorang akan berupaya, bersikap \& bertindak lebih baik. Hal ini selaras menggunakan pendapat Rifai yang menyimpulkan bahwa, belajar memegang peranan penting didalam perkembangan, kebiasaan, sikap, keyakinan, tujuan, kepribadian dan bahkan persepsi seseorang. Oleh karenanya dengan menguasai konsep dasar tentang belajar, seorang mampu tahu bahwa kegiatan belajar memegang peran krusial dalam proses psikologis. (Lubis \& Rusadi, 2019).

Pendidikan berasal dari kata didik yang berarti memelihara dan membentuk latihan, jadi pendidikan adalah suatu usaha yang dilakukan secara sadar dan sengaja untuk mengubah tingkah laku manusia secara individu maupun kelompok untuk mendewasakan manusia melalui upaya pengajaran dan pelatihan.(Subianto, 2013)

Pendidikan adalah investasi dalam pengembangan sumber daya manusia, dan pendidikan adalah bagian penting dari proses pembangunan nasional dan ikut menentukan pertumbuhan ekonomi suatu negara dimana peningkatan kecakapan dan kemampuan diyakini sebagai faktor pendukung upaya manusia dalam mengarungi kehidupan yang penuh dengan ketidakpastian. Dalam kerangka inilah pendidikan dipandang sebagai kebutuhan yang mendasar bagi masyarakat yang ingin maju. Pendidikan memberikan kontribusi yang sangat besar terhadap kemajuan suatu bangsa, dan merupakan wahana dalam menerjemahkan pesan-pesan konstitusi serta sarana dalam membangun watak bangsa. (Fatkuroji, 2017)

Dalam situasi saat ini seperti yang kita ketahui baik pemerintah maupun lembaga-lembaga pendidikan Nasional, Sedang berusaha semaksimal mungkin mengupayakan agar tetap terlaksananya pendidikan dan proses pembelajaran walaupun tidak dilakukan di sekolah. Pada saat ini dunia dihebohkan dengan tersebarnya wabah yang mematikan dan hampir setiap negara di dunia ini mengalaminya. Wabah ini bernama Covid 19, Dampak dari wabah ini sangat dirasakan oleh berbagai aspek yang ada, baik dari 
kemunduran ekonomi, kacaunya sistem dalam negara maupun sistem pendidikan yang ada di berbagai negara. Pihak pemerintah melalui kementrian pendidikan dan pihak-pihak terkait berusaha semaksimal mungkin agar para pelaku pendidikan seperti kepala sekolah, guru, peserta didik dan rule lainnya tetap bisa melakukan proses belajar dan mengajar walaupun dengan cara yang berbeda.

Kemendikbud membuat peraturan bahwa pendidikan di Indonesia tetap berjalan seperti biasanya, tetapi ada hal yang berbeda di dalamnya, Yaitu dengan sistem pembelajaran dari rumah masing-masing. Dalam hal ini khususnya para orangtua peserta didik harus mampu menjalin komunikasi dan interaksi kepada masingmasing anaknya dan mampu untuk membimbing anak-anaknya agar tetap belajar secara maksimal dan optimal walaupun pembelajaran dilakukan di dalam rumah.

Peran aktif menurut orang tua juga sangat membantu proses emosional anak, yang dapat ditinjau menurut bentuk dukungan yang berkaitan dengan pembentukan dan perkembangan emosional anak, yaitu: melepaskan daya kreasi dan imajinasi anak yang berdampak positif \& tentunya anak selalu terarah.

Sebaliknya bila orang tua kurang memberikan perhatian terhadap emosioanl anak seperti sporadis memberikan kesempatan kepada anak, maka akan membawa dampak negatif terhadap perkembangan emosional dalam anak. Sikap saling \& perhatian adalah kunci utama dalam menciptakan suatu hubungan yang serasi antara anak dan orangtua. Pola interaksi yang terjalin secara baik maka menciptakan suasana yang indah dan berdampak positif untuk perkembangan anak tersebut. Dikarenakan jika Ibu dan Bapak dari seorang anak membangun interaksi yang baik dan mendukung serta memotivasi anak supaya tetap semangat dalam pembelajaran walaupun dilakukan dirumah akan membangkitkan motivasi anak dan emosional anak agar lebih semangat dalam belajar dan tidak mudah mengeluh dalam situasi yang terjadi saat ini.

\section{KAJIAN TEORI}

Untuk menopang hasil penelitian maka pada bagian ini akan dikemukakan beberapa teori yang berkaitan dengan konteks penelitian.

\section{Deskripsi tetang Pola Asuh Kedua Orangtua}

Dalam rangka buat membantu anak yang bermasalah dan agar mau buat berkomunikasi menggunakan orang tua maka dituntut suatu pola asuh orang tua yang ideal pada berkomunikasi terhadap anak yang bermasalah tersebut \& mengetahui sebab-sebab yang melatar belakangi sikap \& tindakan anak tersebut. 
Dalam hal menangani masalah anak tersebut orang tua melakukan serangkaikan dialog dengan anak. Interaksi/komunikasi yang baik, hangat dan akrab supaya timbul hasrat buat mengeluarkan kesulitan-kesulitan yang ada dalam diri anak. Proses hubungan antara orang tua dan anak buat mendukung perkembangan fisik, emosi, sosial, intelektual, dan spiritual berlangsung sejak seseorang anak pada kandungan hingga dewasa.(Lubis, Irwanto, \& Harahap, 2019).

Pola asuh bisa diartikan sebagai proses hubungan total antara orang tua dengan anak, yang mencakup pemeliharaan (hadiah makan, membersihkan \& melindungi) dan proses sosialisasi (mengajarkan konduite umum dan sinkron menggunakan aturan pada masyarakat). Proses ini pula melibatkan bagaimana pengasuh (orang tua) mengkomunikasikan efeksi, nilai, minat, konduite \& agama pada anak-anaknya.

Menurut Latifah, pola asuh adalah pola interaksi antara anak dengan orang tua meliputi pemenuhan kebutuhan fisik (misalnya makan, minum \& lain-lain) dan kebutuhan psikologis (misalnya rasa aman, kasih sayang, perlindungan dan lain-lain), serta sosialisasi kebiasaan-kebiasaan yang berlaku di warga agar anak dapat hayati selaras menggunakan lingkungannya. (Lathifah \& Yusniar, 2017).

Pola asuh harus pula berkaitan menggunakan tanggung jawab dan kewajiban orang tua terhadap anak. Menurut Undang-Undang Republik Indonesia Nomor 35 Tahun 2014, Pasal 26, orang tua dalam keluarga berkewajiban dan bertanggung jawab untuk: (a) mengasuh, memelihara, mendidik, \& melindungi anak; (b) Menumbuh kembangkan Anak sesuai dengan kemampuan, bakat dan minatnya; (c) mencegah terjadinya perkawinan pada usia anak; (d) memberikan pendidikan karakter dan penanaman nilai budi pekerti pada anak. Keterlibatan orang tua pada membentuk kepribadian anak bertujuan buat mencegah perilaku menyimpang yang nir sinkron dengan norma susila dan nilai moral dalam diri anak.

Dengan demikian, pola asuh orang tua berarti suatu proses hubungan antara orang tua \& anak yang meliputi kegiatan seperti Misalnya memelihara, mendidik, membimbing dan mendisiplinkan dalam mencapai proses kedewasaan baik secara langsung maupun nir eksklusif.

Orang tua (bapak dan ibu) adalah pendidik kodrati. Mereka pendidik bagi anak-anaknya lantaran secara kodrati ibu \& bapak diberikan pemberian oleh Tuhan pencipta berupa insting orang tua. Karena insting ini, timbul berdasarkan rasa kasih sayang para orang tua pada anak-anak mereka, sampai secara moral keduanya merasa terbebani tanggung jawab buat memelihara, mengawasi, melindungi dan 
mengayomi serta membimbing mereka. (Anisah, 2017).

Hubungan orangtua dengan anak pada famili terjalin melalui hubungan komunikasi yang mereka lakukan sehari-hari. Setiap aktivitas orangtua-anak dapat memilih hubungan komunikasi di antara keduanya. Dalam penelitian ini terdapat kesamaan bahwa orangtua atau anak yang sibuk berkegiatan pada luar rumah sebagai akibatnya intensitas interaksinya berkurang.

Orangtua yang bekerja pada luar kota juga memilih kedekatan anak dengan orangtua pada berkomunikasi. Interaksi komunikasi yang rendah akan menentukan hubungan kedekatan \& keterbukaan orangtua dan anak dalam berkomunikasi. Anak merasa kurang dekat dengan orangtua yang cenderung memiliki poly kegiatan pada luar rumah, begitu pula sebaliknya waktu anak lebih poly menghabiskan waktunya beserta sahabat sebayanya. Walaupun demikian, interaksi komunikasi permanen berlanjut setiap hari, secara eksklusif maupun nir eksklusif (melalui media handphone.

Metode pola asuh yang digunakan sang orang tua pada anak sebagai faktor utama yang memilih potensi dan karakter seseorang anak. Ada banyak jenis-jenis pola asuh yang sering sebagai panduan bagi siapa saja yang ingin mencetak generasi paripurna buat diandalkan bagi kemajuan bangsa ke depan. Jenis pola asuh orang tua ini masing- masing mempunyai karakteristik dan karakteristik khas yang berbeda. Berkaitan dengan jenis jenis pola asuh orang tua, Ada tiga jenis yaitu pola asuh (a) otoriter (Authoritarian), (b) pola asuh demokratis (Authoritative), (c) pola asuh permisif (permissive). (Rakhmawati, 2015)

Pola asuh otoriter adalah cara mendidik anak menggunakan memakai kepemimpinan otoriter, kepemimpinan otoriter yaitu pemimpin menentukan seluruh kebijakan, langkah dan tugas yang harus dijalankan. Sebagaimana diketahui pola asuh otoriter mencerminkan perilaku orang tua yang bertindak keras \& cenderung diskriminatif. Hal ini ditandai menggunakan tekanan anak untuk patuh kepada semua perintah \& asa orang tua, kontrol yang sangat ketat terhadap tingkah laris anak, anak kurang mendapatkan kepercayaan dari orang tua, anak tak jarang di hukum, bila anak menerima prestasi jarang diberi pujian atau hadiah.

Pola asuh orang tua yang otoriter ditandai pada interaksi orang tua menggunakan anak tidak hangat \& acap kali menghukum. Pola asuh otoriter merupakan pola asuh yang ditandai menggunakan cara mengasuh anak-anak menggunakan aturan yang ketat, acapkali kali memaksa anak buat berperilaku misalnya dirinya (orang tua), kebebasan buat bertindak atas nama diri sendiri dibatasi, anak jarang diajak berkomunikasi dan diajak mengobrol, 
bercerita, bertukar pikiran dengan orang tua.

Orang tua malah menduga bahwa semua perilaku yang dilakukan itu sudah sahih sehingga tidak perlu minta pertimbangan anak atas semua keputusan yang mengangkat pertarungan anak-anaknya. Pola asuh yang bersifat otoriter ini juga ditandai menggunakan sanksi yang dilakukan dengan keras, anak juga diatur menggunakan berbagai macam aturan yang membatasi perlakuannya.

Pola asuh demokratis ditandai dengan adanya pengakuan orang tua terhadap kemampuan anak ,anak diberi kesempatan buat tidak selalu tergantung kepada orang tua. Sedikit memberi kebebasan pada anak buat memilih apa yang terbaik bagi dirinya, anak didengarkan pendapatnya, dilibatkan pada pembicaraan terutama yang menyangkut menggunakan kehidupan anak itu sendiri .Anak diberi kesempatan untuk menyebarkan kontrol internal nya sehingga sedikit-sedikit berlatih buat bertanggung jawab pada diri sendiri.

Pola Permisif ialah membiarkan anak bertindak sesuai menggunakan keinginannya, orangtua tidak memberikan hukuman \& pengendalian. Pola asuh ini ditandai menggunakan adanya kebebasan tanpa batas dalam anak buat berperilaku sesuai menggunakan keinginannya sendiri, orang tua tidak pernah menaruh aturan dan pengarahan kepada anak, sebagai akibatnya anak akan berperilaku sesuai menggunakan keinginannya sendiri walaupun terkadang bertentangan dengan norma sosial. (Ayun, 2018).

Orang tua sebagai pendidik yang pertama dan primer mempunyai peran dan fungsi yang sentral pada mendidik \& membentuk kepribadian seorang anak. Proses pendidikan dan pembentukan kepribadian anak tadi terjadi pertama kali di lingkungan keluarga.

Keluarga merupakan komplotan orangtua dan anak-anak. Kebutuhan dan keterikatan anak, kasih sayang \& bisnisbisnis alami menurut orangtua, dan ikatanikatan darah menggunakan seluruh korelasi badani dan rohani membuktikan bahwa keluarga-lah adalah forum sosial alami.

Adanya pencerahan akan tanggung jawab mendidik dan membina anak secara kontinu perlu dikembangkan kepada setiap orang tua sehingga pendidikan yang dilakukan tidak lagi berdasarkan kebiasaan yang dicermati berdasarkan orang tua. (Nazarudin, 2018)

Ada sejumlah pengertian tentang orang tua sebagai pendidik yang pertama \& utama dalam komunitas keluarga. UndangUndang Republik Indonesia Nomor 35 Tahun 2014 tentang Perubahan Atas Undang-Undang Nomor 23 Tahun 2003, (UU RI Nomor 35 Tahun 2014, Pasal 1) mengemukakan bahwa orang tua merupakan ayah \&/atau mak kandung, atau ayah 
dan/atau bunda tiri, atau ayah dan/atau ibu angkat.

Orang tua adalah pendidik yang pertama dan utama yang mempunyai tanggung jawab pada membangun serta membina anak-anaknya baik dari segi psikologis maupun fisiologis.

orang tua dituntut untuk dapat mengarahkan dan mendidik anak-anaknya agar dapat menjadi generasi-generasi yang sesuai dengan tujuan hidup manusia. Keluarga adalah tempat pendidikan awal dan mendasar bagi seorang anak, sebelum seorang anak sungguh-sungguh memasuki lingkungan pendidikan formal seperti halnya sekolah.

Orang tua yang ada pada keluarga merupakan salah satu elemen penting dalam kehidupan masyarakat. Pentingnya bukan hanya menjadi asalmuasal atau sel masyarakat \& negara, tetapi jua karena keluarga selalu ada dalam gerak zaman. Keluarga berjalan mengikuti perubahan zaman tetapi sekaligus pula mengganti zaman pada peradaban manusia. (Rusadi, Widiyanto, \& Lubis, 2019). Perubahan zaman berimplikasi pada aspek-aspek hidup keluarga yaitu kehidupan iman, \& moral. Berkaitan dengan itu tugas pendidikan sebagai semakin berat dalam mempertahankan identitas \& peran keluarga di pada dunia. Orang tua dalam hal ini harus berupaya keras mendidik \& mendampingi anak futuristis yang lebih cerah sesuai tuntutan zaman yang semakin global, termasuk mengantisipasi imbas negatif menurut perkembangan media teknologi \& informasi \& bisa memotivasi diri seorang anak agar konfiden menjadi seorang anak yang disiplin dan konfiden dengan kemampuannya.

Motivasi sangat penting pada proses pengajaran \& pembelajaran karena dia dapat memilih halyang dituju dan kuberkesannya. Pelajar yang bermotivasi tinggi biasanya mempunyai dorongan yang kuatdan mantap buat terus berminat dengan apa yang disampaikan hasil menurut rangsanganrangsangan yang bertenaga yaitu menerusi insentif dan motif. Insentif dalam pengajaran \& pembelajaran sering disampaikan dalam bentuk ekstrinsik seperti markah, pujian, penghargaan, asterik dansebagainya. Motif jua timbul akibat dorongan semula jadi atau kesamaan individu yangmenggerakkan individu buat bertindak dan mencapai suatu keberhasilan walaupun dalam tempoh yang lama.

Motivasi \& belajar merupakan dua hal yang saling mempengaruhi. Belajar adalah perubahan tingkah laku secara relatif permanen dan secara potensial terjadi sebagai hasil menurut praktik atau penguatan (rein forced practice) yang dilandasi tujuan buat mencapai tujuan tertentu".

Lebih lanjut dinyatakan, "pada kegiatanbelajar motivasi bisa dikatakan menjadi holistik daya penggerak di dalam 
diri anak didik yang menimbulkan, mengklaim kelangsungan dan memberikan arah kegiatan belajar, sebagai akibatnya diperlukan tujuan bisa tercapai. (Marisa, Firtiyanti, \& Utami, 2018)

\section{Peran Kedua Orang Tua Dalam Lingkup Keluarga}

Orang tua atau family merupakan lingkungan pertama yang dikenal seorang sejak kelahirannya, di dalam keluarga anak memulai proses pengenalan. Kehidupan sosial anak pada famili kelak akan dibawanya pada kehidupan yang lebih luas, yaitu masyarakat. (Lubis, 2018)

Keluarga adalah sekelompok sosial yang sangat besar pengaruhnya terhadap sosialisasi anak. Peran aktif orang tua terhadap tumbuh kembang anak bisa dipandang dari pendidikan yang diberikan oleh anaknya. Setiap orang tua ingin melihat sosokbuah hatinya menjadi sehat, cerdas \& kreatif. Sebagai orang tentunya dapat mengerti \& memahami dunia anaknya. "Penting untuk diketahui bahwa seorang orang tua adalah pendidik pertama yang menanamkan dasar bagi perkembangan jiwa anak". Karena pendidikan dimulai pada famili, maka sekolah hanyalah pembantu kelanjutan pendidikan tersebut. Peralihan bentuk pendidikan informal menuju ke formal memerlukan kerjasama antara orang tua \& pihak sekolah. Sikap anak terhadap sekolah terutama akan dipengaruhi oleh sikap orang tua juga. (Lubis \& Nasution, 2017).

Interaksi sebagai peristiwa saling mempengaruhi satu sama lain ketika 2 orang atau hadir bersama. Mereka membangun suatu hasil satu sama lain, atau berkomunikasi satu sama lain. Jadi didalam setiap kasus interaksi, tindakan setiap orang buat mensugesti individu lain.(Rodiana, 2006)

Sikap orang tua terhadap anak akan sangat menghipnotis bagaimana seorang Anak itu bisa bersikap pada menjalani kehidupannya sehari-hari. Orang tua yang bersikap otoriter, keras \& menyukai hal-hal yang jelas tidak mencerminkan perilaku baik terhadap anak

Jadi setiap hukuman atau disiplin tidak dicarikan menggunakan kelembutan, penerimaan, \& alasan. Tingkah laku orang tua ini dapat membentuk suatu konsep diri yang menekankan bagi anak buat bersikap arogan, keras kepala, nir penurut, suka melawan.

Banyak orangtua menerapkan konsep atau metode cara mendidik seorang anak yang baro-meternya hanya ambisi supaya anak tersebut harus sesuai dengan apa yang orangtua inginkan \& harapkan.

Bukan konsep bagaimana anak tadi mampu mengerti, tahu apa yang sebagai tanggung jawab seorang anak dalam usianya supaya sanggup menjadi anak yang mempunyai rasa percaya diri dan tanggung 
jawab pada dirinya. Orangtua yang hanya sanggup mendoktrin anak, mendikte anak jangan harap bisa mencetak anak yang berorientasi pada pemahaman anak buat sebagai dirinya percaya diri dan punya rasa tanggung jawab. Anak bukanlah sebuah boneka hanya untuk mainan \& ditimangtimang atau robot yang cara kerjanya hanya menekan tombol on/off, namun anak adalah sebuah individu yang sangat unik bila kita sebagai orangtua mampu memahaminya.

Dorongan sebagai penyemangat agar nir lekas putus asa. Motivasi buat menaruh acuan, sehingga anak mempunyai banyak nasihat sebagai arah jalan hidupnya. Solusi buat membantu merampungkan masalah, Serta dukungan sebagai langkah buat meningkatkan agama dirinya. Apalagi dalam situasi \& syarat yang sedang terjadi dalam waktu ini, Seharusnya orangtua mampu menjalin interaksi yang baik dan selalu memberikan contoh-contoh atau dukungan kepada anaknya agar terus giat dan optimis dalam belajar, Walaupun kegiatan pembelajaran tidak bisa dilakukan seperti biasanya yaitu di sekolah, Tetapi pada saat ini dikarenakan wabah Covid 19 seluruh aktifitas pembelajaran sepenuhnyadilakukan dari rumah.

Seharusnya dilihat dari keputusan yang telah ditetapkan, Para orangtua lebih mampu membentuk atau menjalin pola interaksi terhadap anaknya, agar si anak mampu belajar dan mengingat pembelajaran yang ada walaupun dilakukan melalui Online, tetapi dengan terjalinnya interaksi yang baik antara anak dan orangtua, misalnya orangtua yang mendukung anaknya dan selalu memotivasi atau bahkan memberikan wejangan kepada anaknya agar tetap semangat dalam melakukan pembelajaran dan jangan bosan dengan pembelajaran yang ada, dikarenakan situasi dan kondisi yang memaksakan keadaan jadi seperti ini, Maka dari itu. Sangat pentingnya interaksi atau percakapan yang terjalin antaraIbu dan bapak dengan anaknya.

Dikarenakan dalam pembelajaran yang dilakukan dirumah, Peran orangtua sangat vital dan sangat penting untuk mengawasi anaknya agar tetap melaksanakan pembelajaran dengan maksimal serta tidak melakukan suatu peebuatan yang nyeleneh atau bahkan tidak mau belajar Sama sekali.

\section{Deskripsi tentang Belajar dan Pembelajaran}

Belajar dimaknai menjadi proses perubahan perilaku sebagai output interaksi individu dengan lingkungannya. Perubahan perilaku terhadap output belajar bersifat continiu, fungsional, positif, aktif, dan terarah. Proses perubahan tingkah laris bisa terjadi pada berbagai kondisi berdasarkan penjelasan berdasarkan para pakar pendidikan dan psikologi. Adapun pembelajaran adalah proses hubungan peserta didik dengan pendidik, dengan 
bahan pelajaran, metode penyampaian, taktik pembelajaran, dan asal belajar dalam suatu lingkungan belajar. Kemudian, keberhasilan pada proses belajar \& pembelajaran dapat dilihat melalui tingkat keberhasilan dalam mencapai tujuan pendidikan. (Abtokhi, 2012).

Pembelajaran merupakan susatu sistem, yang terdiri dari berbagai komponen yang saling berafiliasi satu dengan yang lain secara komprehensif. Komponen tadi meliputi: tujuan, materi, metode, dan evaluasi. Keempat komponen tadi harus diperhatikan oleh guru dalam memilih dan memilih pendekatan, dan model model pembelajaran apa yang tepat untuk digunakan dalam proses kegiatan suatu sistem pembelajaran.

Proses pembelajaran merupakan suatu usaha buat membuat anak didik belajar, sehingga situasi tersebut merupakan insiden belajar (event of learning) yaitu bisnis buat terjadinya perubahan tingkah laku dari siswa. Perubahan tingkah laku bisa jua terjadi lantaran adanya hubungan antara murid menggunakan lingkunganya. (Pembelajaran \& Purwokerto) Setiap proses pembelajaran harus menggunakan metodemetode pembelajaran agar pembelajaran tadi dapat maksimal.(Nasution, 2017)

\section{Deskripsi tentang Kebijakan Pembelajaran Di rumah}

Saat ini wabah Covi-19 merupakan penyakit paling berbahaya dan mematikan nomor satu di dunia. Sudah banyak korban yang meninggal global. Hal ini menjadi permasalahan yang harus dihadapi oleh dunia saat ini, buat melakukan banyak sekali kebijakan termasuk pada negara Indonesia sendiri. Dampak yang disebabkan pandemi covid-19 ini, mengakibatkan diterapkannya aneka macam kebijakan buat memutus mata rantai penyebaran virus covid-19 di Indonesia.

Upaya yang dilakukan oleh pemerintah pada Indonesia salah satunya menggunakan menerapkan himbauan pada rakyat agar melakukan physical distancing yaitu himbauan pada masyarakat buat menjaga jeda diantara satu menggunakan yang lainnya, Serta menjauhi aktivitas dalam segala bentuk kerumunan, perkumpulan, dan menghindari adanya pertemuan yang melibatkan banyak orang.

Pemerintah menerapkan kebijakan yaitu Work From Home (WFH). Kebijakan ini adalah upaya yang diterapkan kepada rakyat supaya dapat menyelesaikan segala pekerjaan di rumah. Pendidikan di Indonesia pun menjadi galat satu bidang yang terdampak akibat adanya pandemi covid-19 tersebut.

Salah satu impak pandemi Corona virus artinya terhadap sistem pendidikan di semua global, yang mengarah pada dihentikannya proses belajar mengajar disekolah dan penutupan semua sekolah, madrasah, universitas, \& pondok pesantren. 
Kami turut merasakan impak tadi berupa perubahan pelaksanaan pembelajaran di madrasah \& pondok pesantren.(Purwanto, 2020).

Kementerian Pendidikan yang terdapat di Indonesia pula mengeluarkan kebijakan yaitu menggunakan meliburkan sekolah \& mengubah proses Kegiatan Belajar Mengajar (KBM) menggunakan menggunakan sistem dalam jaringan (daring). Dengan diberlakukan-nya sistem pembelajaran secara daring ini, terkadang muncul berbagai perkara yang dihadapi oleh siswa dan guru, seperti bahan ajar yang belum terselesaikan disampaikan sang guru lalu guru mengubah menggunakan tugas lainnya. Pandemi Covid-19 turut mengubah dunia pendidikan, mulai menurut metode pembelajaran, penganggaran, sampai sasarannya. Metamorfosis ini membutuhkan adaptasi supaya aktivitas belajar-mengajar berjalan efektif.

Dalam proses belajar, misalnya, guru nir lagi wajib bertatap muka secara langsung menggunakan murid karena bisa dilakukan secara daring. Pendidikan jua bukan hanya diukur saat ujian, melainkan juga menghadirkan solusi atas persoalan yang sedang terjadi. "Covid-19 telah membawa perubahan, termasuk dunia pendidikan. Pendidikan bukan lagi urusan persiapan mencari kerja, melainkan mengestafetkan peradaban lebih baik ke generasi selanjutnya.
(Darmalaksana, Hambali, Masrur, \& Muhlas, 2020)

Konflik lain menurut adanya sistem pembelajaran secara online merupakan akses informasi yang terkendala sang frekuwensi yang mengakibatkan lambatnya pada mengakses fakta. Siswa terkadang tertinggal menggunakan warta dampak dari frekuwensi yang kurang memadai. Akibatnya mereka terlambat dalam mengumpulkan suatu tugas yang diberikan oleh guru. Kedisiplinan anak didik waktu belajar diharapkan sebagai kapital bagi mereka untuk disiplin menjalankan pembatasan sosial. Dengan begitu, mereka mendukung upaya pemerintah dalam memutus rantai penyebaran wabah virus corona yang mematikan.

Terkait perkembangan era globalisasi saat ini, dimana SDGs digaungkan sebagai sistem pembangunan berkelanjutan, tidak secara menyentuh pengembangan sistem pendidikan jarak jauh menjadi rumusan yang di kembangkan secara luas di Indonesia. Hal ini secara prinsip dalam proses pelaksanaannya terkendala dengan sumber Daya Manusia yang sangat minim di Negara Indonesia ini dalam pelaksanaan Pendidikan, Pembelajaran, Pembinaan dan Pelaksanaan serta Pengelolaan yang dikhususkan dalam lingkup pengembangan di sektor pendidikan khususnya. (Taufik, 2019)

Pentingnya penggunaan media dalam pembelajaran, diperkuat oleh 
pendapat Edgare Dale yang mengemukakan teori yang lalu lebih dikenal menggunakan teori Kerucut Pengalaman. Adanya pandemi covid-19 bisa menaruh hikmah yang mendalam. Pembelajaran yang dilakukan di rumah, bisa menciptakan orang tua lebih mudah dalam memantau atau mengawasi terhadap perkembangan belajar anak secara langsung.

Orangtua lebih mudah dalam membimbing \& mengawasi belajar anak dirumah. Hal tadi akan menimbulkan komunikasi yang lebih intensif dan akan menimbulkan hubungan kedekatan yang lebih erat antara anak \& orang tua. Orang tua bisa melakukan pembimbingan secara langsung pada anak tentang materi pembelajaran yang belum dimengerti oleh anak.

Dimana sebenarnya orang tua adalah institusi pertama pada pendidikan anak. Dalam aktivitas pembelajaran secara online yang diberikan oleh guru, Maka orang tua bisa lebih leluasa untuk memantau sejauh mana kompetensi dan kemampuan anaknya. Kemudian ketidakjelasan berdasarkan materi yang diberikan oleh guru, membuat komunikasi antara orang tua menggunakan anak semakin terjalin dengan baik. Orang tua dapat membantu kesulitan materi yang dihadapi oleh seluruh anak yang kesulitan dalam proses pembelajaran.

\section{METODE PENELITIAN}

Dalam penelitian yang berjudul Pola interaksi anak dan orangtua selama kebijakan pembelajaran dirumah Penulis menggunakan metode jenis penelitian studi Kasus. Dipilihnya penelitian studi kasus karena penelitian ini fokus untuk menganalisis permasalahan yang terjadi pada beberapa individu yang menjadi objek penelitian saja.(Creswell, 2018)

Penelitian ini memusatkan diri secara intensif dalam satu obyek eksklusif yang mempelajarinya menjadi suatu perkara. Data studi perkara dapat diperoleh menurut seluruh pihak yang bersangkutan, menggunakan kata lain pada studi ini dikumpulkan menurut berbagai sumber.

Penelitian studi kasus akan kurang kedalamannya bilamana hanya dipusatkan pada fase tertentu saja atau keliru satu aspek tertentu sebelum memperoleh gambaran generik tentang masalah tersebut. Sebaliknya studi kasus akan kehilangan artinya jikalau hanya ditujukan sekedar untuk memperoleh gambaran umum namun tanpa menemukan sesuatu atau beberapa aspek khusus yang perlu dipelajari secara intensif dan mendalam. Studi perkara yang baik wajib dilakukan secara langsung pada kehidupan sebenarnya menurut masalah yang diselidiki. Walaupun demikian, data studi perkara bisa diperoleh tidak saja dari perkara yang diteliti, tetapi, pula dapat diperoleh berdasarkan seluruh pihak yang mengetahui dan 
mengenal perkara tersebut menggunakan baik. Dengan kata lain, data dalam studi perkara dapat diperoleh menurut aneka macam sumber namun terbatas dalam masalah yang akan diteliti.(Sugiyono, 2018)

\section{Tempat dan waktu Penelitian}

Penelitian ini dilakukan di Jln. Veteran Psr 7 Helvetia, lingkungan XII Kabupaten Deli Serdang. Waktu yang Digunakan Untuk Penelitian ialah dari bulan maret 2020 sampai dengan mei 2020 .

\section{Subjek Penelitian}

Subjek penelitian ialah keluarga yang berada pada lokasi penelitian dan dalam hal ini di fokuskan kepada beberapa rumah saja yakni hal ini dikarenakan kasusnya hanya terjadi pada keluarga tersebut saja..

\section{Teknik Pengumpulan data}

Observasi atau pengamatan secara langsung Dilakukan oleh peneliti buat mengumpulkan data yang sinkron menggunakan sifat penelitian lantaran mengadakan pengamatan secara langsung atau diklaim pengamatan terlibat dimana peneliti juga menjadi instrumen atau alat dalam penelitian sehingga peneliti wajib mencari data sendiri dengan terjun eksklusif atau mengamati dan mencari pribadi ke beberapa informan yang sudah ditentukan sebagai sumber data.

Metode observasi ini peneliti menentukan jenis observasi partisipatif adalah observasi yang sekaligus melibatkan diri selaku orang dalam dalam situasi tertentu. Hal ini agar memudahkan peneliti memperoleh data atau informasi menggunakan mudah dan leluasa.

\section{Teknik analisis data}

Menggunakan jenis Teori Induksi, Yaitu : Peneliti harus memfokuskan perhatiannya dalam data yang dilapangan sehingga segala sesuatu tentang teori yang herbi penelitian sebagai tidak penting.

Data akan menjadi sangat penting, sedangkan teori akan dibangun berdasarkan temuan data pada lapangan. Data merupakan segalanya yang dapat memecahkan semua perkara penelitian. Posisi peneliti sahih-sahih bereksplorasi terhadap data, \& apabila peneliti secara kebetulan telah memiliki pemahaman teoritis tentang data yang akan di teliti, proses pembuatan teori itu wajib dilakukan.

\section{HASIL DAN PEMBAHASAN}

Kebijakan pembelajaran di rumah yang ditetapkan oleh Kemendikbud awalnya memang sangat tidak terduga dan seharusnya tidak terjadi, tetapi dikarenakan situasi dan kondisi saat ini yang memang tidak memungkinkan suatu proses pembelajaran di lembaga sekolah, Alasannya agar mencegah wabah Corona agar tidak terlalu jauh menyebar dan menimbulkan efek buruk khususnya pada bidang pendidikan. kemendikbud berupaya semaksimal mungkin agar para pelaku pendidikan, seperti guru sampai kepada 
peserta didik harus tetap bisa mendapatkan pembelajaran yang layak dan optimal walaupun situasi dan kondisi yang sangat tidak mendukung.

Dari hasil pengamatan penulis mengenai pola interaksi antara anak dan orang tua selama kebijakan pembelajaran dirumah, babyak hal yang penulis dapatkan dan banyak hikmah uang bisa diambil di dalamnya.

Dengan diberlakukannya kebijakan pembelajaran dirumah, hubungan seorang anak dengan kedua orang tua yang sebelumnya bisa dikatakan belum optimal atau mungkin sekedarnya saja, Namun saat ini orangtua mampu untuk mengawasi dan berperan penting demi kemajuan dan kelancaran proses pembelajaran anaknya. Orang tua harus mampu menjadi seorang yang mampu memotivasi dan memberikan semangat kepada anaknya agar tetap selalu semangat dalam melakukan pembelajaran dan tidak mudah mengeluh atas apa yang terjadi saat ini.

Ibu dan Bapak dari seorang anak harus mampu membuat anaknya menjadiorang yang baik, mendidiknya supaya tidak menjadi seornag pemalas dantidak berkompeten. Sikap orang tua kepada anaknya Sangat mensugesti bagaimana seorang anak itu bersikap dalam menjalani kehidupan sehari-hari.

Seperti penelitian ini dilakukan oleh penulis bahwa seorang anak SD yang bernama Askar Khairan habib mendapatkan perhatian yang sangat tinggi dan sangat optimal dari kedua orang tuanya. Kedua orang tuanya selalu mendukung nya agar tetap semangat belajar dan menemani anaknya serta menjawab apa saja yang ditanyakan oleh anaknya perihal pembelajaran.

Hal ini patut dicontoh dan diaplikasikan oleh para orang tua lainnya, dikarenakan sikap Orang tua yang baik terhadap anaknya, akan mendidik dan melahirkan sikap seorang anak yang baik pula. Begitu pula sebaliknya, Jika orang tua kasar dan bersikap acuh serta tidak memperdulikan anaknya, Maka kelak Anak tersebut akan tumbuh menjadi seseorang anak yang pembangkang \& buruk perilakunya.

Maka pada hal ini dapat diambil Kesimpulan bahwa didikan orang tua sangat akbar pengaruhnya terhadap perkembangan sikap, psikologis seorang Anak. Maka sebaiknya sebagai orang tua selalu memberikan arahan-arahan terbaik dan motivasi kepada anaknya agar anaknya tidak menjadi seorang yang tidak mau perduli dengan nasehat ataupun ucapan orang lain.

Kebijakan pembelajaran dirumah dapat dikatakan banyak hikmahnya juga, dikarenakan pola hubungan antara Anak dan orang tua bisa lebih terjalin dan orang tua bisa lebih mengawasi anak-anaknya dalam proses pembelajaran yang dilakukan secara 
daring dirumah. Apalagi anak tersebut masih dalam masa perkembangan, Maka orang tua harus menaruh perhatian khusus dan mengamati anak tersebut, supaya tidak salah arah dan selalu menuju jalan kebaikan lewat arahan-arahan ataupun Nasehat yang diberikan sang orang tua kepada Anaknya.

\section{SIMPULAN}

Pendidikan merupakan usaha untuk menaikkan diri dalam banyak sekali aspeknya. Pendidikan adalah suatu yang integral menurut kehidupan. Pendidikan merupakan investasi pada pengembangan asal daya manusia dan merupakan bagian penting menurut proses pembangunan nasional, Serta ikut menentukan pertumbuhan ekonomi pada suatu negara dimana peningkatan kecakapan dan kemampuan diyakini sebagai factor buat mendukung upaya manusia pada mengarungi kehidupan.

Kemendikbud membuat peraturan bahwa pendidikan di Indonesia tetap berjalan misalnya biasanya, tetapi sistem pembelajaran dilakukan dari rumah masingmasing. Proses belajar mengajar tetap berlangsung walaupun dilakukan di masingmasing tempat tinggal para pendidik dan peserta didik.

Dalam hal ini kiprah orangtua sangat krusial demi mendukung anaknya agar tetap disiplin dan semangat dalam proses pembelajaran dirumah.
Dikarenakan hanya orangtualah yang mampu memotivasi anaknya agar semangat menjalani pembelajaran, Meskipun dalam situasi dan kondisi yang sedang mengkhawatirkan, Dikarenakan negara Indonesia ini sedang dilanda wabah Covid 19 yang membuat semua aspek-aspek kehidupan menjadi kacau, terutama dalam bidang pendidikan.

Pola interaksi yang baik harus dilakukan oleh orangtua kepada anaknya agar menentukan keberhasilan diri seorang anak dalam menjalani pembelajaran dirumah. Orang tua seharusnya selalu mendampingi anaknya dalam proses pembelajaran yang dilakukan dirumah, dikarenakan jika seorang anak tidak diperhatikan oleh orangtuanya, maka ia akan malas-malasan dalam belajar dan mengakibatkan dirinya tidak mendapatkan pengetahuan dari pembelajaran daring yang dilakukan dirumah masing-masing.

Dikarenakan orangtua berperan sebagai pendidik yang pertama \& primer yang memiliki tanggung jawab untuk menciptakan dan membina anak-anaknya baik menjadi seorang anak yang baik perilakunya, mentalnya dan hati-nya.

Tanggung jawab sebagai orangtua harus bisa memotivasi anaknya agar menjadi seseorang anak yang disiplin \& konfiden menggunakan potensi dirinya sendiri. Sikap Ibu \& Bapak terhadap anak akan sangat mempengaruhi bagaimana perangai atau 
tingkah laku anak di dalam kehidupannya sehari-hari.

Adanya pandemi covid 19 banyak memberikan hikmah yang sangat mendalam bagi seluruh aspek kehidupan terutama anatara anak dan orangtua, Dikarenakan membuat hubungan orangtua \& anak menjadi lebih dekat dan orangtua lebih dengan mudah mengawasi atau mengontrol perkembangan pembelajaran anaknya selama kebijakan pembelajaran dirumah agar dapat berjalan dengan baik dan benar.

\section{DAFTAR PUSTAKA}

Abtokhi, A. (2012). Peran Ibu dalam Kegiatan Pendampingan Belajar Anak Melalui Prinsip Individual LearningCentered. Egalita. 4(1), 80-90.

Anisah, A. S. (2017). Pola asuh orang tua dan implikasinya terhadap pembentukan karakter anak. Jurnal Pendidikan Uniga, 5(1), 70-84.

Ayun, Q. (2018). Pola asuh orang tua dan metode pengasuhan dalam membentuk kepribadian anak. Journal Ta'dib, 3(1), 15.

Creswell, J. w. (2018). Penelitian Kualitatif dan Desain Riset; Memilib di Antara Lima Pendekatan (5th ed.). Bandung: Pustaka Pelajar.

Darmalaksana, W., Hambali, R., Masrur, A., \& Muhlas, M. (2020). Analisis Pembelajaran Online Masa WFH Pandemic Covid-19 sebagai Tantangan Pemimpin Digital Abad 21. Karya Tulis Ilmiah (KTI) Masa Work From Home (WFH) Covid-19 UIN Sunan Gunung Djati Bandung, 1-12.

Fatkuroji, F. (2017). Implementasi Kebijakan Pembelajaran Terpadu dan Minat Pelanggan Pendidikan. Tarbawi: Jurnal Keilmuan Manajemen Pendidikan,
2(02), 28-40.

Kemendiknas. Undang-Undang No. 20 tabun 2003 Tentang Sistem Pendidikan Nasional. ,(2003).

Lathifah, Z. K., \& Yusniar, E. (2017). Pengaruh pola asuh orang tua terhadap motivasi belajar siswa kelas iv sdn tarikolot 06 Bogor. UNES Journal of Education Scienties, 1(1), 107-115.

Lubis, R. R. (2018). Optimalisasi Kecerdasan Spiritual Anak. Jurnal AlFatih, 1(1), 1-18.

Lubis, R. R., Irwanto, I., \& Harahap, M. Y. (2019). Increasing Learning Outcomes and Ability Critical Thinking of Students Through Application Problem Based Learning Strategies. International Journal for Educational and Vocational Studies, 1(6), 524-527.

Lubis, R. R., \& Nasution, M. H. (2017). Implementasi Pendidikan Karakter di Madrasah. JIP (Jurnal Ilmiah PGMI), 3(1), 15-32.

Lubis, R. R., \& Rusadi, B. E. (2019). Problematika Implementasi Scientific Approach dalam Pembelajaran Fikih (Studi Kasus Di MTs. PAI Medan). Intiqad: Jurnal Agama Dan Pendidikan Islam, 11(1), 118-134.

Marisa, C., Firtiyanti, E., \& Utami, S. (2018). Hubungan Pola Asub Orangtua dengan Motivasi Belajar Remaja. 6, 25-32.

Nasution, M. K. (2017). Penggunaan Metode Pembelajaran Dalam Peningkatan Hasil Belajar Siswa. 11(1), 9-16.

Nazarudin, M. (2018). Pola Kerja sama Guru dan Orang Tua dalam Meningkatkan Mutu Pendidikan di MIN 2 Kota Palembang. 24(2).

Purwanto, A. (2020). Studi Eksplorasi Dampak Work From Home (WFH) Terhadap Kinerja Guru Selama Pandemi Covid-19. EduPsyCouns: Journal of Education, Psychology and Counseling, 2(1), 92-100.

Rakhmawati, I. (2015). Peran keluarga dalam 
pengasuhan anak. Jurnal Bimbingan Konseling Islam, 6(1), 1-18.

Rodiana, L. (2006). Terhadap Kreativitas Verbal Siswa Kelas 2 Smp Dharma Wanita Malang Terhadap Kreativitas Verbal Siswa Kelas 2 Smp Dharma Wanita Malang. Journal Hikmah, 4(1), 56.

Rusadi, B. E., Widiyanto, R., \& Lubis, R. R. (2019). Analisis Learning And Inovation Skills Mahasiswa Pai Melalui Pendekatan Saintifik Dalam Implementasi Keterampilan Abad 21. Conciencia, XIX(2), 112-131. https://doi.org/https://doi.org/10.19 109/conciencia.v19i2.4323

Subianto, J. (2013). Peran Keluarga, Sekolah, dan Masyarakat Pembentukan Karakter Berkualitas. Edukasia: Jurnal Penelitian Pendidikan Islam, 8(2), 331-354. https://doi.org/10.21043/edukasia.v8i 2.757

Sugiyono. (2018). Metode Penelitian Kuantitatif, Kualitatif, dan $\mathrm{R}$ \& $D$ (10th ed.). Bandung: Alfabeta.

Taufik, A. (2019). Perspektif Tentang Perkembangan Sistem Pembelajaran Jarak. Jauh Di Kabupaten Kutai Kartanegara Kalimantan Timur. 3(2), 88-98. 